\title{
Discussing inequalities from the periphery
}

\author{
ERIKA NAGY ${ }^{1}$
}

Recently, the Hungarian Geographical Bulletin - that had been a forum for introducing empirically focused papers covering various social and physical geographical issues for decades - became engaged increasingly in academic discourses on socio-spatial inequalities, embracing various approaches and problems with different scalar foci. The theoretical and methodological diversity that ranged from classical spatial analysis through humanistic geography to critical structuralism and post-structuralism represented a shift not only toward a conceptual openness in geographical discourses but also to a (more) socially engaged research agenda. This multiplicity and the 'internationalisation' of the journal - the switch for English language and the growing number of international authors - involved the Bulletin in academic discourses revolving around the major problems of socio-spatial polarisation, marginality, dependence and exclusion in European and also in global context. This special issue is meant to contribute to these ongoing debates on the diverse forms, contexts and processes of the (re)production of socio-spatial polarisation - form a Central and East European perspective, bringing authors together from various institutions and countries working together in the Marie Curie ITN project 'Socio-economic and Political Responses to Regional Polarisation in Central and Eastern Europe' $\left(\operatorname{RegPol}^{2}\right)^{2}$.

Socio-spatial inequalities that manifested at multiple scales along various (economic, demographic, social, environmental, political, etc.) dimensions in Europe and deepened further as a consequence of the recent crisis have raised criticism towards the neoliberalisation of principles and institutional practices of European and national policies, as well as towards the scholarly concepts that underpinned them. A growing body of academic research focused on socio-spatial polarisation - including East-West differences - explaining the process in the context of the global capital flows, European division of labour and of imbalanced power relations (in economy, politics and knowledge production) driving political discourses on development and cohesion and thus, the social construction of cores and peripheries (see e.g. Sмітн, A. and Pickles, J. 1998; Smith, A. and Timár, J. 2010; Hajdimichalis, C. 2011; Ehrlich, K. et al. 2012; Hirt, S. et al. 2013). Moreover, series of studies focused on daily social practices at local scale in transition societies - revealing, how peripherality and marginality is experienced and responded to - raised a concern with agency and socio-cultural (historical) diversity in spaces labelled 'backward' or 'peripheral' in popular and political discourses (see e.g. Hörschelmann, K. 2001; Váradi, M. 2005; Stenning, A. et al. 2011; NAgy, E. et al. 2015).

The evolving debates on macrostructural processes, discourses and daily lives (re-)producing unevenness stimulated the critical revision of embedded concepts of centrality, peripherality, polarisation and peripheralisation, raising arguments for relational thinking

\footnotetext{
${ }^{1}$ Centre for Economic and Regional Studies, Hungarian Academy of Sciences; H-5600 Békéscsaba, Szabó Dezső u. 42. E-mail: nagye@rkk.hu

2 "Socio-economic and Political Responses to Regional Polarisation in Central and Eastern Europe" $\left(\operatorname{RegPol}^{2}\right)$, coordinated by the Leibniz Institute for Regional Geography, Leipzig, Germany. The project received funding from the People Programme (Marie Curie Actions) of the European Union's Seventh Framework Programme FP7/2007-2013/ under REA grant agreement n 607022.
} 
on power, agency and discursive constructions of space - and against dichotomies-led thinking (MAssey, D. 2008; Berndt, M. and Colini, L. 2013; Lang, T. 2015 in this issue).

This special issue does not endeavour to give an overview of recent debates over the above notions. However, the papers question earlier argumentations, reveal the diversity of concepts of polarisation and peripheralisation, and contribute to their re-conceptualisation explicitly - by discussing the related theories critically - or implicitly - by employing relational approach and focusing on agency and on the social constructions of space. Thus, it is a forum not only for addressing the shortcomings of earlier research but also for challenging the dominant discourses on peripheralisation and polarisation 'from the periphery'3, contributing to more balanced - socially and spatially 'equal' - relations in academic discussions and in policy making.

In his lead-off paper, Thilo LANG focuses on the problems and dilemmas related to the conceptualisation of the persistence and the recent, crisis-driven deepening of sociospatial inequalities within Europe, stressing the complexity, interrelatedness and the multiscalar nature of structural changes, discourses and social practices that produce uneven social geographies manifesting in intra-urban, urban/rural, metropolitan/nonmetropolitan, and East-West European polarities. He highlights the shortcomings of the foregoing research that failed to excavate the social relations driving peripheralisation and polarisation processes of and within Central and Eastern Europe through policy discourses and institutional practices, moreover, to address the entanglement of manifold core-periphery relations and their variegated socio-cultural contexts. A new analytical concept is proposed in the paper,

\footnotetext{
${ }^{3}$ I refer here to the ongoing discussion on marginalisation of social groups and spaces in academic and public discourses and to the arguments - forwarded by postcolonial theorists - for involving such groups in the debates to reconstruct socio-spatial realities (see e.g. STENNING, A. and Hörschelmann, K. 2008; KuUs, M. 2013; SHARP, J. 2011).
}

interpreting the notions of centralisation and peripheralisation as processes driven by multiple social relations, and the refocusing our research on how centrality and peripherality is constructed, performed, reacted to and reproduced by interactions and strategies of social agents linked to various scales. In this way, the paper contributes to avoiding the fallacies of dichotomy-biased thinking on the (re)production of inequalities in CEE and beyond - driving academic discourses often unperceived.

József Benedek and Aura Moldovan focuses on a more specific aspect of spatial inequalities - yet contributing to the re-conceptualisation of academic research on this major issue. They provide a critical overview of approaches and concepts discussing economic growth, convergence, and polarisation to reveal their interrelatedness and to develop a relevant framework for explaining economic inequalities. Their discussion embraces

(i) the traditional and the new growth theories as well as the New Economic Geography that provide a sophisticated yet a limited (hard production factor-focused) explanation of persisting inequalities;

(ii) selected concepts of sociology and history advancing the introduction of new ("soft") factors and of the time dimension into academic discourse, and thus, paving the way for new explanations of unequal economic development as a multidimensional process;

(iii) various concepts of polarisation that help to explain inequalities in the context of the global economy defined by highly imbalanced power relations. The authors argue for combining various social and economic factors (dimensions) in the convergence studies, for the introduction of the micro and the global scale into such analyses, moreover, for understanding convergence/divergence and economic growth as strongly interrelated processes that have a cumulative effect of spatial inequalities.

Bradley Loewen's paper contributes to the re-conceptualisation of academic research 
on socio-spatial inequalities proposed also by Thilo LANG. LoEwen calls for a critical analysis of European Cohesion Policy and of the related discourses to reveal the causal relations of the neoliberalisation of European policies and of the national institutional practices with regional (sub-national) polarisation processes. He argues that the shift in the principles of EU Regional Policy (from cohesion toward competitiveness) along with the normative approach driving European institutional practices enhanced socio-spatial inequalities - instead of easing them by capitalising on regional qualities and diversity celebrated in policy discourses. He suggests to get a deeper understanding of various national socio-cultural and political contexts in which, such policies and practices are unfolding - for which, he proposes the Comparative Historical Analysis as a relevant conceptual framework - and reveal the power relations that underpin the discourses on regional development at various scales to move beyond the Neoliberal normativity of recent regional policies that cannot counteract to socio-spatial polarisation processes.

Péter BALOGH's paper takes us into the realm of popular discourse, focusing on the interrelatedness and the mutually constitutive nature of the material reality of peripherality, its perceptions and of the artistic and popular scientific constructions of marginal spaces. Relying mostly on the illustrative case of County Békés in Southeast Hungary, the author takes a historical journey across the $20^{\text {th }}$ century. He analyses critically, how peripherality was perceived and constructed in sociographic monographs of the interwar period and under socialism, and in the literary sources and art films of the (post-)transition times - focusing not just on the content, but discussing also the wider social contexts as well as the authors' reflexions on their own position. BALOGH also contrasts the realities showed by artists and scientists to the romanticised and commercial images of peripheral spaces in popular scientific journals highlighting, how peripherality is constructed 'from outside', driven by non-local intellectuals. The author's argumentation draws the reader's attention to the problem of positionality and the need for (self-)reflexivity - issues scarcely discussed in CEE-focused studies, so far.

The contribution of Garri RAAgmaA and Grete KINDEL put agency and social networks in the focus of their analysis. Discussing changing local social relations in two peripheral Estonian communities targeted by wellof urban dwellers seeking for second home they reveal, how the entry of a social group with major social capital assets (recreational home owners) has transformed local political landscapes. They point out that, while this powerful group extended its control over local processes - by exploiting their local and non-local networks - and stimulated structural changes for their own benefit, local residents' interests and needs were pushed into the background. The paper throws lights upon the significance of agency in local processes, and argues for discussing this issue in the context of highly complex power relations linked to various scales - to understand the contested nature of transformations in peripheral communities. By this, the authors also challenge the positive meanings of the notions of change and development in relation to peripheral spaces and call for including the emerging powerlessness and marginality in our research agenda.

\section{REFERENCES}

Berndt, M. and Colini, L. 2013. Exclusion, marginalization and peripheralization. Working Paper 49. Berlin, Leibniz Institute for Regional Development and Structural Planning.

Ehrlich, K., Kriszan, A. and Lang, T. 2012. Urban Development in Central and Eastern Europe - Between Peripheralization and Centralization? disP - The Planning Review 48. (2): 77-92.

Hadjimichalis, C. 2011: Uneven geographical development and socio-spatial justice and solidarity: European regions after the 2009 financial crisis. European Urban and Regional Studies 18. (3): 254-274.

Hirt, S., Sellar, C. and Young, C. 2013. Neoliberalism Meets the Eastern Bloc: Resistance, Appropriation and Purification in Post-socialist Spaces. EuropeAsia Studies 65. (7): 1243-1254. 
Hörschelmann, K. 2001. Breaking ground Marginality and resistance in (post) unification Germany. Political Geography 20. (8): 981-1004.

KuUs, M. 2013. Places of lower rank: Margins in conversations. Political Geography 37. 30-32.

LANG, T. 2015. Socio-economic and Political Responses to Regional Polarisation and Socio-spatial Peripheralisation in Central and Eastern Europe: a research agenda. Hungarian Geographical Bulletin, 64. (3): 171-185.

Massey, D. 2008. For Space London, SAGE

Nagy, E., Timár, J., Nagy, G. and Velkey, G. 2015. The Everyday Practices of the Reproduction of Peripherality and Marginality in Hungary. In Understanding Geographies of Polarization and Peripheralisation. Eds.: LANG, T., HenN, S., EhrLich, K. and Sgibnev, W. Basingstoke, Palgrave. 135-155.

Sharp, J. 2011. Subaltern geopolitics: Introduction. Geoforum 42. (3): 271-273.

Smith, A. and PickLEs, J. 1998. Introduction: Theorising transition and the political economy of transformation. In Theorising transition. Eds.: PICKLes, J. and Sмiтh, A. London, Routledge, 1-23.
Sмiтh, A. and Timár, J. 2010. Uneven transformations: Space, economy and society 20 years after the collapse of state socialism. European Urban and Regional Studies, 17. (2): 115-125.

Stenning, A., Smith, A., Rochovska, A. and Swiatek, D. 2011. Domesticating Neoliberalism. Spaces of Economic Practice and Social Reproduction in Postsocialist Cities. Oxford, Wiley-Blackwell.

Stenning, A. and Hörschelmann, K. 2008. History, geography and difference in the post-socialist world: or, do we still need post-socialism? Antipode 40. 312-335.

VÁRADI, M. 2005. Increasingly Fossilised Labour Market Structures and Strategies of Livelihood: Chances of Disadvantaged Groups in the Labour Market. In Hungarian Spaces and Places: Patterns of Transition. Eds.: BARTA, GY., G. FeKeTE, É., SzÖRÉNYIKukorelli, I. and Timár, J. Pécs, Centre for Regional Studies of the Hungarian Academy of Sciences, 289-306. 